J. Electroanal. Chem., 221 (1987) 239-243

Elsevier Sequoia S.A., Lausanne - Printed in The Netherlands

Short communication

\title{
ELECTROCHEMICAL PROCEDURE FOR THE DEVELOPMENT OF LARGE ACTIVE SURFACE AREA PLATINUM ELECTRODES WITH PREFERRED CRYSTALLOGRAPHIC ORIENTATIONS
}

\author{
A. VISINTIN, W.E. TRIACA and A.J. ARVIA \\ Instituto de Investigaciones Fisicoquimicas Téricas y Aplicadas (INIFTA) ${ }^{\star}$, Casilla de Correo 16, Sucursal \\ 4, (1900) La Plata (Argentina)
}

(Received 17th July 1986; accepted 11th December 1986)

The development of electrocatalysts with optimal performance implies the rational handling of both the active surface area with the greatest accessibility for reactants and the energy distribution of active sites. This requires firstly the production of electrodes of large active surface area with negligible mass transport and ohmic polarization, and secondly the development of a particular crystallographic orientation. For the case of platinum it is possible to accomplish an increase in active surface area either through a two-stage procedure, namely, by forming a thick oxide layer under fast periodic potential signals covering relatively large potential windows, followed by a complete electroreduction scan [1], or through a single-stage procedure by applying a potential cycling at an intermediate frequency in a rather small potential window [2]. Both procedures yield an increase in the active surface area without appreciable faceting. Conversely, preferred crystallographic orientations are brought about through fast potential cycling covering only a relatively narrow potential window $[2,3]$. In this case the process implies practically no change in surface roughness. The development of either a large active surface area or a preferred crystallographic orientation has also been achieved independently for other metals (gold, rhodium, silver and copper) [4-8]. At this stage, it was considered of the utmost importance to attempt a procedure through which the two effects could combine in such a way that the active surface area would increase and the development of preferred crystallographic orientation take place together under controlled conditions. This would offer a method for electrode surface modification particularly interesting for application to electrodes on a technical scale.

\footnotetext{
Facultad de Ciencias Exactas, Universidad Nacional de La Plata.
} 
This communication reports, for the first time, preliminary data concerning an electrochemical procedure involving the simultaneous increase in active surface area and development of either (100)- or (111)-type preferred oriented platinum surfaces.

Runs were made in $1 \mathrm{M} \mathrm{H}_{2} \mathrm{SO}_{4}$ at $25^{\circ} \mathrm{C}$ with both polycrystalline platinum (Johnson Matthey Chem. Co.) wires and spheres as working electrodes (0.01-0.1 $\mathrm{cm}^{2}$ geometric area). The latter were prepared by melting platinum wires of $0.5 \mathrm{~mm}$ diameter using a hydrogen + oxygen flame. The potential of the working electrode was measured against a RHE in the same acid solution. A large-area platinum counterelectrode surrounding the working electrode concentrically was used. The electrochemical cell and instrumentation have been described elsewhere [3].

Prior to each experiment the working electrode was potential cycled at $0.3 \mathrm{~V} / \mathrm{s}$ between $0.04 \mathrm{~V}$ and $1.50 \mathrm{~V}$ during $15 \mathrm{~min}$ to attain a stabilized voltammogram. After the pretreatment, the working electrode was firstly subjected to a relatively low-frequency $\left(f_{1}\right)$ repetitive square-wave potential signal (RSWPS) between lower $\left(E_{1}\right)$ and upper $\left(E_{\mathrm{u}}\right)$ potential limits immediately followed by a second RSWPS at a higher frequency $\left(f_{2}\right)$ between the same potential limits. The low-frequency RSWPS applied during the time $t_{1}$ is mainly associated with the increase in active surface area, whereas the fast RSWPS applied during the time $t_{2}$ is responsible for the preferred crystallographic orientation.

The increase in active surface area together with the development of the (100)-type preferred oriented platinum surface can be obtained under the following conditions: $E_{1}=0 \mathrm{~V}, E_{\mathrm{u}}=1.4 \mathrm{~V}, f_{1}=25 \mathrm{~Hz}, t_{1}=5 \mathrm{~h}, f_{2}=4 \mathrm{kHz}, t_{2}=5 \mathrm{~h}$. The comparison between the voltammogram at $0.3 \mathrm{~V} / \mathrm{s}$ of the untreated specimen and that of the surface resulting after the combined RSWPS shows a substantial increase in the H-adatom voltammetric charge (relative surface area increase about 10 ) and a predominant current contribution of strongly bound $\mathrm{H}$-adatoms, as one should expect for the development of the (100)-type preferred crystallographic orientation [9-14] (Fig. 1a). Independent experiments made for the sake of comparison show that, at low-frequency RSWPS, the increase in active surface area with a minor development of the (100)-type preferred crystallographic orientation becomes the predominant fact (Fig. 1b), whereas at high-frequency RSWPS the main effect is the development of the (100)-type preferred crystallographic orientation with a negligible increase in active surface area (Fig. 1c).

Similar experiments were performed to obtain the increase in active surface area together with the (111)-type preferred crystallographic orientation. In this case, when the platinum working electrode is subjected to a combined RSWPS treatment with the following characteristics: $E_{1}=0.70 \mathrm{~V}, E_{\mathrm{u}}=1.35 \mathrm{~V}, f_{1}=1.2 \mathrm{kHz}, t_{1}=4.5$ $\mathrm{h}, f_{2}=6 \mathrm{kHz}, t_{2}=4 \mathrm{~h}$, the voltammogram run immediately afterwards at $0.3 \mathrm{~V} / \mathrm{s}$ in the $0.04 \mathrm{~V}-1.50 \mathrm{~V}$ range shows a remarkable increase in the voltammetric charge related to both the $\mathrm{H}$-adatom and the $\mathrm{O}$-adatom monolayers, as compared to that of the blank (relative surface area increase about 10 ), and significant changes in the $\mathrm{H}$ and $\mathrm{O}$-adatom current peaks in the direction expected for the development of the (111)-type preferred crystallographic orientation [9,11,15-17] (Fig. 2a). In addition, independent experiments show that for exclusively low-frequency RSWPS treat- 


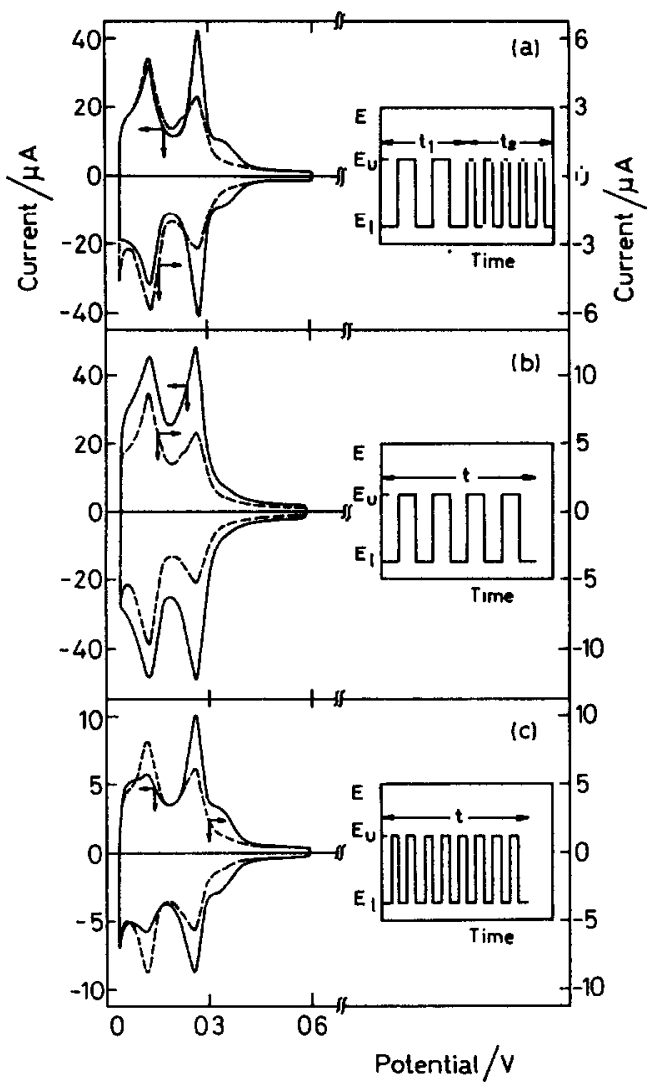

Fig. 1. Voltammograms run at $0.3 \mathrm{~V} / \mathrm{s}$ in $1 \mathrm{M} \mathrm{H}_{2} \mathrm{SO}_{4}$ at $25^{\circ} \mathrm{C}$. (- - Untreated platinum electrodes (blanks). (- (a) After a combined RSWPS treatment ( $E_{1}=0 \mathrm{~V}, E_{\mathrm{u}}=1.4 \mathrm{~V}, f_{1}=25 \mathrm{~Hz}$, $\left.t_{1}=5 \mathrm{~h}, f_{2}=4 \mathrm{kHz}, t_{2}=5 \mathrm{~h}\right)$. (b) After a single RSWPS treatment $\left(E_{1}=0 \mathrm{~V}, E_{\mathrm{u}}=1.4 \mathrm{~V}, f=25 \mathrm{~Hz}\right.$, $t=5 \mathrm{~h})$. (c) After a single RSWPS treatment $\left(E_{1}=0 \mathrm{~V}, E_{\mathrm{u}}=1.4 \mathrm{~V}, f=4 \mathrm{kHz}, t=5 \mathrm{~h}\right)$. The potential/time programs applied to the electrodes are also depicted for each figure.

ment, the predominant effect corresponds to the increase in active surface area (Fig. $2 \mathrm{~b}$ ), whereas for high-frequency RSWPS treatment the development of the (111)-type preferred crystallographic orientation is the major effect (Fig. 2c). This conclusion is supported by crystallographic evidence [18] showing that the application of RSWPS of characteristics close to those used in the present case to a single crystal platinum sphere produces the disappearance of [110] and [100] poles and the development of symmetric grooves which connect the [111] poles.

Otherwise, it should be noticed that other combinations of periodic potential perturbations, including changes in the symmetry of the RSWPS, also become useful for the achievement of large active surface areas with different preferred 


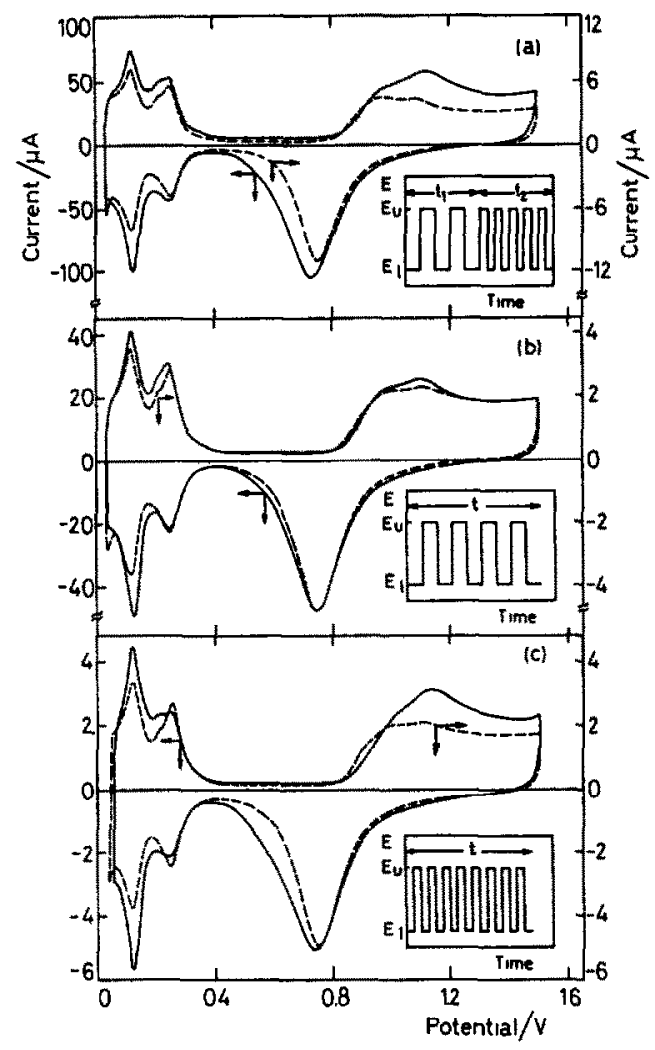

Fig. 2. Voltammograms run at $0.3 \mathrm{~V} / \mathrm{s}$ in $1 \mathrm{M} \mathrm{H}_{2} \mathrm{SO}_{4}$ at $25^{\circ} \mathrm{C}$. (- - Untreated platinum electrodes (blanks). (- ( ) After a combined RSWPS treatment $\left(E_{1}=0.70 \mathrm{~V}, E_{\mathrm{u}}=1.35 \mathrm{~V}, f_{1}=1.2\right.$ $\mathrm{kHz}, t_{1}=4.5 \mathrm{~h}, f_{2}=6 \mathrm{kHz}, t_{2}=4 \mathrm{~h}$ ). (b) After a single RSWPS treatment $\left(E_{1}=0.70 \mathrm{~V}, E_{\mathrm{u}}=1.35 \mathrm{~V}\right.$, $f=1.2 \mathrm{kHz}, t=4.5 \mathrm{~h})$. (c) After a single RSWPS treatment $\left(E_{1}=0.70 \mathrm{~V}, E_{\mathrm{u}}=1.35 \mathrm{~V}, f=6 \mathrm{kHz}, t=4\right.$ h). The potential/time programs applied to the electrodes are also depicted for each figure.

crystallographic orientations. The voltammetric behaviour of the resulting electrode surfaces resembles that of large active area platinum electrodes in the absence of pores [19].

The overall process, related to the increase in the active surface area, is mainly concerned with either a redistribution of surface metal atoms brought about by forming and breaking $\mathrm{Pt}-\mathrm{O}$ bonds $[20]$ or platinum electrodissolution/electrodeposition during cycling [21] or the electroreduction of a hydrous $\mathrm{O}$-containing surface layer produced on platinum [17], whereas the electrochemical faceting with preferred crystallographic orientation occurs through fast $\mathrm{OH}$-species electroadsorption/electrodesorption cycles coupled to selective electrodissolution of the base metal and electrodeposition of soluble platinum species [3,7] assisted through the build-up of a pulsating diffusional layer $[22,23]$. 


\section{ACKNOWLEDGEMENTS}

This work was supported financially by the Universidad Nacional de La Plata, the Consejo Nacional de Investigaciones Científicas y Técnicas and the Comisión de Investigaciones Científicas de la Provincia de Buenos Aires.

This work was also supported in part by the Regional Program for the Scientific and Technological Development of the Organization of American States.

\section{REFERENCES}

1 A.C. Chialvo, W.E. Triaca and A.J. Arvia, J. Electroanal. Chem., 146 (1983) 93.

2 R.M. Cerviño, W.E. Triaca and A.J. Arvia, J. Electroanal. Chem., 182 (1985) 51.

3 W.E. Triaca, T. Kessler, J.C. Canullo and A.J. Arvia, J. Electrochem. Soc., in press.

4 A.C. Chialvo, W.E. Triaca and A.J. Arvia, J. Electroanal. Chem., 171 (1984) 303.

5 C.L. Perdriel, A.J. Arvia and M. Ipohorski, J. Electroanal. Chem., 215 (1986) 317.

6 E.R. Custidiano, S. Piovano, A.J. Arvia, A.C. Chialvo and M. Ipohorski, J. Electroanal. Chem., 221 (1987) 229.

7 A.J. Arvia, J.C. Canullo, E. Custidiano, C.L. Perdriel and W.E. Triaca, Electrochim. Acta, 31 (1986) 1359.

8 A.C. Chialvo, W.E. Triaca and A.J. Arvia, J. Electroanal. Chem., submitted.

9 A.T. Hubbard, R.M. Ishikawa and J. Katekaru, J. Electroanal. Chem., 86 (1978) 271.

10 E. Yeager, W.E. O'Grady, M.Y.C. Woo and P. Hagans, J. Electrochem. Soc., 125 (1978) 348.

11 K. Yamamoto, D.M. Kolb, R. Kötz and G. Lehmpfuhl, J. Electroanal. Chem., 36 (1979) 233.

12 P.N. Ross, Jr., Surf. Sci., 102 (1981) 463.

13 J. Clavilier, R. Durand, G. Guinet and R. Faure, J. Electroanal. Chem., 127 (1981) 281.

14 C.L. Scortichini and C.N. Reilley, J. Electroanal. Chem., 139 (1982) 233.

15 P.N. Ross, Jr., J. Electroanal. Chem., 76 (1977) 139.

16 P.N. Ross, Jr., J. Electrochem. Soc., 126 (1979) 67.

17 J. Clavilier, R. Faure, G. Guinet and R. Durand, J. Electroanal. Chem., 107 (1980) 205.

18 J.C. Canullo, W.E. Triaca and A.J. Arvia, J. Electroanal. Chem., 200 (1986) 397.

19 M.S. Piovano, A.C. Chialvo, W.E. Triaca and A.J. Arvia, J. Appl. Electrochem., in press.

20 T. Biegler, J. Electrochem. Soc., 114 (1967) 1261.

21 D.F. Untereker and S. Bruckenstein, J. Electrochem. Soc., 121 (1974) 360.

22 N. Ibl, Surf. Technol., 10 (1980) 81.

23 J.Cl. Puippe and N. Ibl, J. Appl. Electrochem., 10 (1980) 775. 